\title{
THE EFFECT OF MUDHARABA, MUSHARAKA, AND IJARA FINANCING TO RETURN ON EQUITY IN BANK BRI SHARIA PERIOD 2016-2020
}

\author{
Filia Fransiska ${ }^{1}$, Asmak Ab Rahman ${ }^{2}$, Shinta Maharani ${ }^{3}$ \\ ${ }^{13}$ The State of Islamic Studies Ponorogo, Indonesia \\ ${ }^{2}$ Department of Sharia and Economics, Academy of Islamic Studies, University of \\ Malaya, Malaysia \\ Email: filiafrancisca@gmail.com ${ }^{1}$, asmak@um.edu.my ${ }^{2}$, maharani@iainponorogo.ac.id ${ }^{3}$
}

\begin{abstract}
Aim of this research is the phenomenon on the 2016-2020 financial statements of BRI Syariah Bank. It shows that the increase in income is not always followed by an increase in Return On Equity (ROE) at BRI Syariah Bank, vice versa. The purpose of this study was to determine the effect of Mudharaba, musyaraka, and Ijara both in the long and short term on Return On Equity (ROE). The method of this study used quantitative methods, and used secondary data. The population and sample used in this study are BRI Syariah Bank monthly reports, including Mudharaba, musyaraka, and Ijara in the 2016-2020 period. The analytical method used is the Error Correction Model (ECM) with the Eviews program. The results in this study indicate that in the short term and long term, Mudharaba has a significant positive effect on return on equity (ROE), the shortterm results show that the $t$-statistic (t-count) is greater than the t-critical $(2.833045>2.002247)$. Meanwhile, the results of the longterm test show that the t-statistic (t-count) is more significant than t-critical (2.467613 >2.002247). Musharaka in the short term and long term affects the return on equity (ROE). The short-term results show that the $t$-statistic ( $t$-count) is greater than the t-critical (2.909601 >2.002247). Meanwhile, the results of the long-term test show that the $t$-statistic (t-count) is more significant than $t$-critical $(2.733504>2.002247)$. While Ijara in the short term and the long term does not affect the return on equity (ROE), the shortterm results show that the t-statistic (t-count) is greater than the $t$ critical (1.330407<2.002247). Meanwhile, the results of the long-term test show that the $t$-statistic (t-count) is more significant than t-critical $(1.256261<2.002247)$. Simultaneously, in the short term, Mudharaba, Musharaka, and Ijara have a significant and positive effect on the return on equity (ROE) of $23.8249 \%$. While in the long term, it has a significant effect of $28.3164 \%$.
\end{abstract}

Keywords: Return on Equity, Mudharaba, Musharaka, Ijara

\section{INTRODUCTION}

The profitability used to measuring the bank's ability to earn a profit or overall profit. High profitability can indicate an excellent financial performance of the bank. Conversely, if the profitability achieved is low, the financial performance is less than optimal in generating profits. If low profitability continues, it will impact the low image of the bank in the eyes of the public. A decrease in public trust can cause raising funds to become problematic(Aditya, 2016, p. 2). 
In this study, researchers used one of the profitability ratios, namely ROE ( Ratio On Equity), or it can be said that ROE is the primary indicator of profitability ratios. ROE ( Ratio On Equity) is a ratio to measure net income after tax with own capital(Harahap, 2018, p. 140). ROE measures the results of both company owners' ordinary and preferred shareholders' capital invested in the company. A high level of ROE indicates that the company generates a high net income. If the net profit generated is high, then the management performance. Based on the publication of Islamic banking statistics conducted by the FSA (the authority of services financial) shows, Musharaka and Ijara in Bank BRI Syariah period 2016-2020.

Table 1. Mudharaba and ROE 2016-2020 PT Bank BRI Syariah (In Millions of Rupiah)

\begin{tabular}{lcc}
\hline \multicolumn{1}{c}{ Period } & Mudharaba & ROE \\
\hline 2016 June & $1,356,304$ & 0.041 \\
\hline 2016 July & $1,327,496$ & 0.045 \\
\hline 2017 January & $1,246,387$ & 0.005 \\
\hline 2017 February & $1,229,349$ & 0.011 \\
\hline 2018 June & 648,128 & 0.024 \\
\hline 2018 July & 621,859 & 0.026 \\
\hline 2019 Sep & 407,037 & 0.011 \\
\hline 2019 Okt & 409,534 & 0.005 \\
\hline 2020 January & 399,631 & 0.004 \\
\hline 2020 Feb & 385,467 & 0.008 \\
\hline
\end{tabular}

Source: BRI sharia bank financial statements for the 2016-2020 ('Bank BRI Syariah', 2020)

Table 2. Musharaka and ROE 2016-2020 PT Bank BRI Syariah (In Millions of Rupiah)

\begin{tabular}{lcc}
\hline \multicolumn{1}{c}{ Period } & Musyaraka & ROE \\
\hline 2016 June & $5,266,046$ & 0.041 \\
\hline 2016 July & $5,180,997$ & 0.045 \\
\hline 2017 January & $5,262,550$ & 0.005 \\
\hline 2017 February & $5,153,859$ & 0.011 \\
\hline 2018 June & $6,958,811$ & 0.024 \\
\hline 2018 July & $6,946,986$ & 0.026 \\
\hline 2019 September & $9,904,817$ & 0.011 \\
\hline 2019 Oktober & $10,247,430$ & 0.005 \\
\hline 2020 June & 366,416 & 0.022 \\
\hline 2020 July & 352,909 & 0.027
\end{tabular}

Source: BRI sharia bank financial statements for the 2016-2020 ('Bank BRI Syariah', 2020) 
Table 3. Ijara and ROE 2016-2020 PT Bank BRI Syariah (In Millions of Rupiah)

\begin{tabular}{lcc}
\hline \multicolumn{1}{c}{ Period } & Ijara & ROE \\
\hline 2016 January & 42,378 & 0.006 \\
\hline 2016 February & 38,558 & 0.009 \\
\hline 2017 November & $1,110,735$ & 0.064 \\
\hline 2017 December & $1,146,920$ & 0.040 \\
\hline 2018 September & $1,636,088$ & 0.030 \\
\hline 2018 Oktober & $1,646,511$ & 0.018 \\
\hline 2019 November & $1,608,524$ & 0.005 \\
\hline 2019 December & $1,597,231$ & 0.014 \\
\hline 2020 April & $1,474,093$ & 0.018 \\
\hline
\end{tabular}

Source: BRI sharia bank financial statements for the 2016-2020 ('Bank BRI Syariah', 2020)

In table 1, it can be seen that the Mudharaba of PT Bank BRI Syariah has increased and vice versa. In June -July 2016, Mudharaba 28,808 decreased, but the ROE increased by $0.004 \%$. In January -February 2017, Mudharaba 17,038 decreased, but the ROE increased by $0.006 \%$. In June -July 2018, Mudharaba 26,269 decreased, but the ROE increased by $0.002 \%$. In September - October 2019, Mudharaba 2,497 increased. Otherwise, the ROE decreased by $0.006 \%$. In January -February 2020, Mudharaba 14,164 decreased, then the ROE increased by $0.004 \%$.

In table 2, it can be seen that the Musharaka of PT Bank BRI Syariah has increased and also decreased. In June-July 2016, Musharaka 85,049 decreased, but the ROE increased by $0.004 \%$. In January-February 2017, Musharaka 108,691 decreased, but the ROE increased by $0.006 \%$. In June-July 2018, Musharaka 11,825 decreased, but the ROE increased by $0.002 \%$. In September-October 2019, Musharaka increased by 342,613 , but the ROE decreased by $0.006 \%$. In June -July 2020, Musharaka 13,507 decreased, but the ROE increased by $0.005 \%$.

In table 3, it can be seen that the Musharaka of PT Bank BRI Syariah has increased and also decreased. In January -February 2016, Musharaka 3,820 decreased, but the ROE increased by $0.003 \%$. In November-December 2017, Musharaka 36,185 increased, but the ROE $0.034 \%$ decreased. In September -October 2018, Musharaka increased by 10,423 , but the ROE of $0.012 \%$ decreased. In NovemberDecember 2019, Musharaka decreased by 11,293, but the ROE was $0.009 \%$ increased. In April -May 2020, Musharaka decreased by 86,645, but the ROE increased by $0.002 \%$. Based on the description of the table above, it can be concluded that the 
increase in income is not always followed by an increase in ROE at BRI Syariah Bank. On the other hand, a decrease in income. is not always followed by a decrease in ROE at BRI Syariah Bank. It is not under the theory which states that "If increases, the return on equity (ROE) also increases(Aziza \& Diana, 2021, p. 36)."

\section{LITERATURE REVIEW}

\section{Return On Equity (ROE)}

$\mathrm{ROE}$ is a tool commonly used by investors and company leaders to measure how much profit the company gets from its capital. For investors, the analysis of Return On Equity (ROE) becomes essential because it can be seen the benefits that can be obtained from the investments made. For companies, this analysis is crucial because it is an attractive factor for investors to invest in(Wiroso, 2011, p. 45). Equity, commonly referred to as capital, is the fund invested by the owner in establishing a business to finance bank business activities and comply with government regulations(Andrianto \& Firmansyah, 2019, p. 26).

This ratio is a number that is the result of a comparison between profit and total equity. The higher the ROE number obtained, it can be said that the company will be better. As we all know, the principle of economics is to try to get as much profit as possible with the least amount of capital. If the capital used is significant, then the ROE will be smaller. Conversely, if the capital used is small, the ROE number will be even more significant(Satria \& Saputri, 2016, p. 56).

\section{Financial Sharia}

Law Number 10 of 1998 concerning states that based on sharia principles is the provision of money or an equivalent claim, based on an agreement or agreement between the bank and another party that requires the party being financed to return the money or claim after a certain period in return for or profit-sharing(Faradilla, Arfan, \& Shabri, 2017, p. 11). Borrowing money or bills based on an agreement or loan agreement between a bank and another party that requires the borrower to repay the debt after a specific time with the amount of interest, compensation, or profitsharing(Soemitra, 2016, p. 76). The main tasks of banks, providing fund facilities to meet the needs of parties who are deficit units(Soemitra, 2019, p. 116). It can be 
concluded that is funding given to a party to support planned activities or businesses. Borrowers are required to pay off.

\section{RESEARCH METHODS}

In this study, researchers used quantitative research with an associative approach. Quantitative research is research conducted by collecting data in the form of numbers, and the data is processed and analyzed to obtain information. In this study, there is one dependent variable, Return On Equity(ROE), and three independent variables; Mudharaba, Musharaka, and Ijara. The data used in this research is secondary data. Secondary data is data collected not only for a particular research or briefly secondary data, data that other parties have collected. Secondary data was also collected based on existing sources. This study uses financial report data from OJK and www.brisyariah.co.id from 2016-2020. The data analysis technique used Error Correction Model (ECM) to determine the short-term and long-term effects of independent variables on the dependent variable, including overcoming non-stationary data and the problem of blunt regression. The tools used in this study to process and analyze existing data are Econometric Views (Eviews) software version 10 and Microsoft Excel 2013. Five stages of testing must be carried out, including Data Stationarity Test, Cointegration Test, Short-Term Model, Test Classical Assumptions, and Long-Term Models.

\section{RESULTS AND DISCUSSION}

Data statistics are used to describe generalizations.

Table 4. Mean, Median, Maximum, and Minimum Data of Each Research Variable

\begin{tabular}{lcccc}
\hline \multicolumn{1}{c}{ Score } & mean & median & Maximum & Minimum \\
\hline Return On Equity (ROE) (\%) & 0.025 & 0.0205 & 0.067 & 0.001 \\
\hline Mudharaba (Million Rupiah) & 755,871 & 634,993 & $1,356,304$ & 315,016 \\
\hline Musharaka (Million Rupiah) & $8,052,565$ & $6,911,420$ & $15,077,529$ & $4,999,565$ \\
\hline Ijara (Million Rupiah) & $1,069,503$ & $1,268,822$ & $1,708,165$ & 19,314 \\
\hline
\end{tabular}

Source: Secondary Data Processed Using Eviews 10, 2021

Based on the statistical data presented in table 4 above, an overview of the dependent variable and each independent variable is obtained as follows:

Based on Table 4, it can be seen that Return On Equity (ROE) has an average value of $0.025000 \%$, a middle value of $0.020500 \%$, a maximum value of $0.067000 \%$, 
and a minimum value of $0.001000 \%$. The highest number of Return On Equity (ROE) occurred in December 2016, while the lowest Return On Equity (ROE) occurred in January 2019. Based on Figure 1, Return On Equity (ROE) as a whole continues to change, and these changes tend to be unstable. From 2016 to 2017, Return On Equity (ROE) tended to increase, but from 2018 to 2019, the number of Return On Equity (ROE) tended to decrease, and it will increase again in 2020.

Based on table 4, it can be seen that Mudharaba has an average value of 755,871 , a median value of 634,993 , a maximum value of $1,356,304$, and a minimum value of 315,016. Total Mudharaba was highest in June 2016, while the sheer number of Mudharaba lowest occurred in December 2020. Based on Figure 2, Mudharaba tends to decrease significantly from 2016 to 2020.

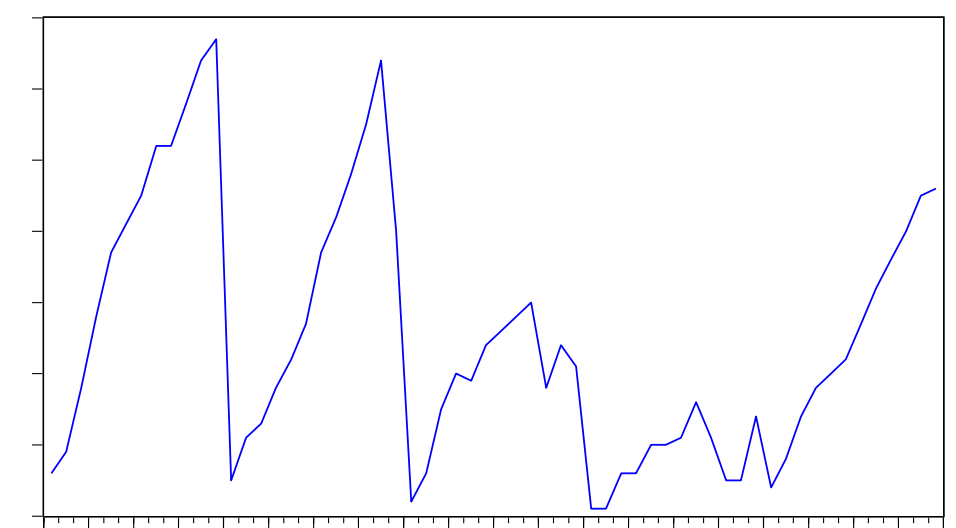

Source: Secondary Data Processed Using Eviews 10, 2021

Figure 1. Total Return On Equity (ROE) Monthly BRI Syariah Bank Period 20162020

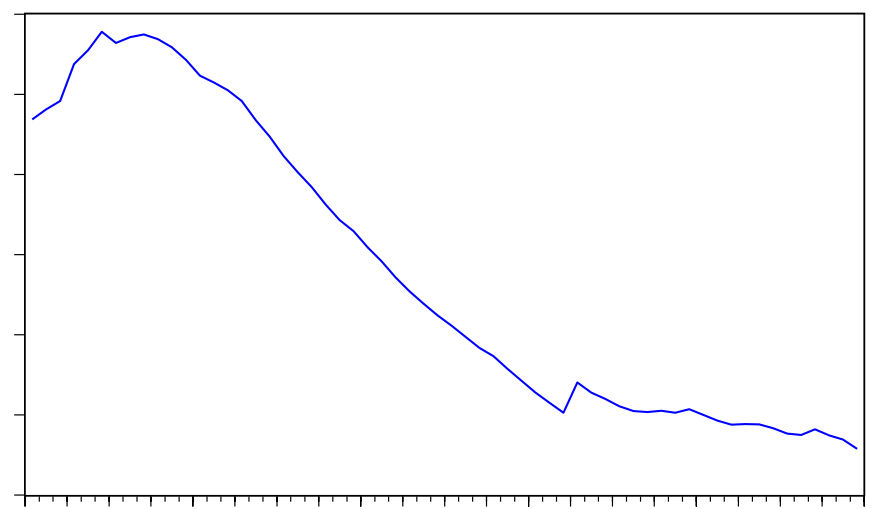

Source: Secondary Data Processed Using Eviews 10, 2021

Figure 2. BRI Syariah Bank Monthly Mudharaba 2016-2020 period 


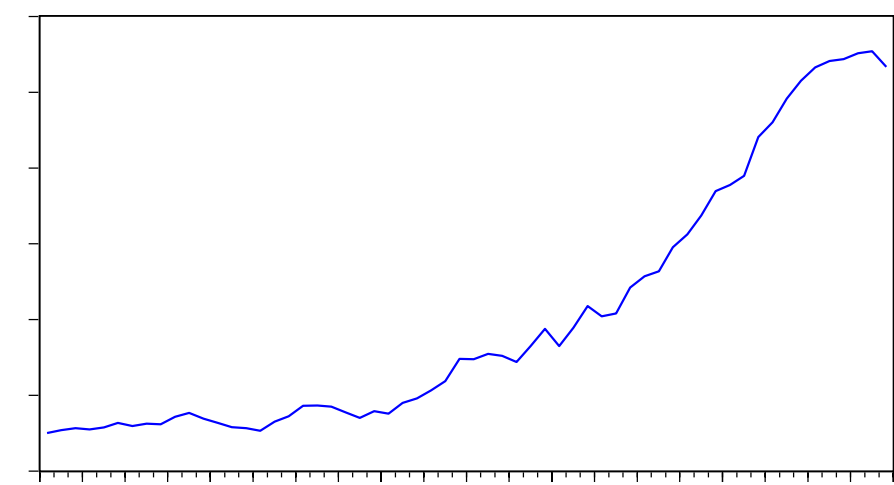

Source: Secondary Data Processed Using Eviews 10, 2021

Figure 3. Amount of Monthly Musharaka BRI Syariah Bank 2016-2020 period

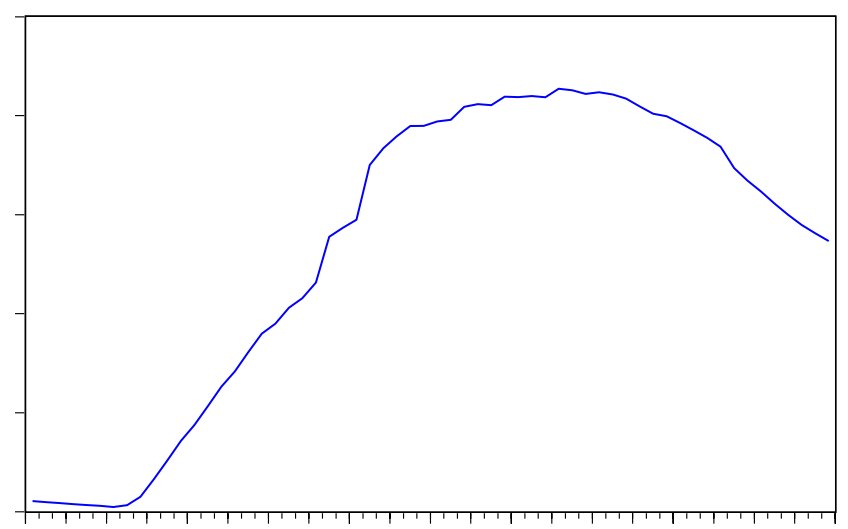

Source: Secondary Data Processed Using Eviews 10, 2021

Figure 4. BRI Syariah Bank Monthly Ijara for the 2016-2020 Period

Based on table 4, it can be seen that Musharaka has an average value of $8,052,565$ million rupiahs, a median value of 6,911,420 million rupiahs, a maximum value of 15,077,529 million rupiahs, and a minimum value of 4,999,565 million rupiahs. The highest Musharaka occurred in June 2016, while the lowest amount of Musharaka occurred in December 2020. Based on Figure 3, Musharaka tends to increase continuously from 2016 to 2020.

Based on table 4, it can be seen that Ijara has an average value of 1,069,503 million rupiahs, a median value of 1,268,822 million rupiahs, a maximum value of 1,708,165 million rupiahs, and a minimum value of 19,314. Total Ijara was highest in April 2019, while the sheer number of Ijara lowest occurred in July 2016. Based on Figure 4, Ijara as a whole tends to increase and decrease. From 2016 to mid-2019, Ijara tends to increase, but from mid-2019 to 2020, Ijara has decreased. 
Niqosiya: Journal of Economics and Business Research

Vol. 1 No. 2, Juli-Desember 2021: 268-285

\section{Error Correction Model (ECM) Test}

\section{Stationarity Test Data: Root Test Unit (Unit Root Test )}

This study uses the unit root test or the Augmented Dickey-Fuller (ADF) root test. This ADF test is often used to detect whether the data is stationary or not. If the ADF stationarity test results produced at the level indicate that the data is not stationary, then the ADF stationary test can be performed at the second difference level. This step is carried out until all data variables are at a stationary level. The results of the Augmented Dickey-Fuller stationary test at the level are shown in Table 5

Table 5. Augmented Dickey-Fuller Test Results at level

\begin{tabular}{cccc}
\hline Variable & ADF value test stat & Probability & Information \\
\hline Mudharaba & -0.764152 & 0.8213 & Not Stationary \\
\hline Musharakah & -0.621898 & 0.8570 & Not Stationary \\
\hline Ijara & -2.751073 & 0.0720 & Not Stationary \\
\hline Return on Equity (ROE) & -2.596332 & 0.0994 & Not Stationary \\
\hline
\end{tabular}

Source: Secondary Data Processed Using Eviews 10, 2021

Table 6 Augmented Dickey-Fuller Test Results at the second difference level

\begin{tabular}{cccc}
\hline Variable & ADF value test stat & Probability & Information \\
\hline Mudharaba & -11.83853 & 0.0000 & Stationary \\
\hline Musharakah & -12.29823 & 0.0000 & Stationary \\
\hline Ijara & -11.74709 & 0.0000 & Stationary \\
\hline Return on Equity (ROE) & -7.403694 & 0.0000 & Stationary \\
\hline
\end{tabular}

Source: Secondary Data Processed Using Eviews 10, 2021

Based on Table 5, it can be seen that all variables; Mudharaba, Musharaka, Ijara, and Return on Equity (ROE), are not stationary at the level of the resulting ADF profitability, greater than 0.05 . Because all variables are not stationary, then the Augmented Dickey-Fuller stationarity test is carried out at the first difference level, but if it is not stationary, use the next level, the second difference. The Augmented DickeyFuller stationary test results at the second difference level can be seen in Table 6 .

Based on Table 6 above, it can be seen that the probability value of the variable Mudharaba, Musharaka, Ijara, and Return on Equity(ROE) is less than 0.005. That is, at the second difference level, all variables are stated to be stationary. 


\section{Cointegration Test}

After performing the stationarity test, the next step is to perform a cointegration test which aims to determine whether or not there is cointegration in variable data that shows a short-term and long-term relationship between variables. In this study, the Augmented Dickey-Fuller cointegration test was used. The requirement to meet the criteria if the variables studied are cointegrated to look at the behavior of the residuals from the regression equation used, namely the residuals must be stationary where the probability value is less than 0.05 . The following results of the regression residual stationarity test can be seen in Table 7

Table 7. Residual Regression Stationarity Test

\begin{tabular}{cccc}
\hline Augmented Dickey- & t-Statistics & Probability & Information \\
\cline { 2 - 4 } Filler test statistics & -3.550705 & 0.0099 & Stationarity \\
\hline
\end{tabular}

Source: Secondary Data Processed Using Eviews 10, 2021

Based on Table 7, the probability value shows the number 0.0099. Because the resulting probability value is less than 0.005 , the residual value is stationary. So it can be concluded that there is a cointegration or long-term relationship between the variables of Mudharaba, Musharaka, and Ijara on return on equity (ROE).

\section{Short-Term Relationship Model}

Table 8 Short-term Regression Test Results

\begin{tabular}{lllll}
\hline Variable & Coefficient & Std. Error & t-Statistics & Prob. \\
\hline C & 0.726214 & 0.191510 & 3.792033 & 0.0004 \\
D(MDH) & 1.541095 & 5.439715 & 2.833045 & 0.0065 \\
D(MSY) & 1.525598 & 5.243324 & 2.909601 & 0.0052 \\
D(IJR) & 3.840173 & 2.886465 & 1.330407 & 0.1890 \\
EC-2 & 0.363338 & 0.095799 & 3.792719 & 0.0004 \\
\hline R-squared & 0.290783 & Mean dependent var & 0.000678 \\
Adjusted R & 0.238249 & SD dependent var & 0.011677 \\
SE of regres & 0.010192 & AIC & -6.253532 \\
SS resid & 0.005609 & SIC & -6.077470 \\
Likelihood logs & 189.4792 & Hannan Quinn Criter. & -6.184804 \\
F-statistics & 5.535088 & Durbin-Watson stat & 1.659268 \\
Prob(F-statistic) & 0.000828 & & \\
\hline
\end{tabular}

Source: Secondary Data Processed Using Eviews 10, 2021 
Based on the table 8 , the following equations are obtained from the short-term estimation results:

\section{$($ ROE $)=0.726214+1.541095(\mathrm{MDH})+1.525598 \Delta(\mathrm{MSY})+3.840173 \Delta(\mathrm{IJR})+$ 0.363338 (EC-2)}

The short-term regression results in Table 8 can be explained as follows: The variable (Mudharaba) with a t- statistic value of 2.833045 , the data processing results indicate that the Mudharaba variable has a positive coefficient. Then obtained t-critical in the table with $(0.05)$ and $\mathrm{df}=\mathrm{nk}(\mathrm{df}=60-3=57)$, which is equal to 2.002247 , it can be seen that the $\mathrm{t}$ - statistic (t-count) is more significant than $\mathrm{t}$-critical $(2.833045$ $>2.002247$ ), then rejecting Ho1 means that in the short term, Mudharaba has a significant effect on return on equity (ROE). When Mudharaba increases, the return on equity (ROE) decreases. When the change in Mudharaba increased by $1 \%$, the return on equity (ROE) decreased by 1.541095 million rupiahs with the assumption that other variables were constant.

The variable (Musharaka) with a t- statistic value of 2.909601, the results of the data processing indicate that the Musharaka variable has a positive coefficient. Then obtained t-critical in the table with (0.05) and $\mathrm{df}=\mathrm{nk}(\mathrm{df}=60-3=57)$, which is equal to 2.002247 , it can be seen that the $\mathrm{t}-$ statistic ( $\mathrm{t}$-count) is more significant than $\mathrm{t}$-critical (2.909601 >2.002247), then rejects Ho3, which means that in the short term, Mudharaba .

Effect on return on equity (ROE). When musharaka increases, the return on equity (ROE) decreases. When the change in Musharaka increased by $1 \%$, the return on equity (ROE) decreased by 1.525598 million rupiahs with the assumption that other variables were constant. The variable ( Ijara ) with at- Statistic value of 1.330407, the data processing results indicate that the Ijara variable has a positive coefficient. Then obtained t-critical in the table with $(0.05)$ and $\mathrm{df}=\mathrm{nk}(\mathrm{df}=60-3=57)$, which is equal to 2.002247 , it can be seen that the $\mathrm{t}$ - statistic (t-count) is more significant than $\mathrm{t}$-critical $(1.330407<2.002247)$, then accepting Ho4 means that in the short term Ijara does not affect the return on equity (ROE).

\section{Long-Term Relationship Model}

Based on the table above, the following equations are obtained from the longterm estimation results: 


\section{$\mathrm{ROE}=-\mathbf{0 . 0 9 7 6 5 9}+\mathbf{8 . 3 1 2 3 9 6}($ Mudharaba $)+\mathbf{5 . 0 4 5 9 8 0}($ Musharaka $)+$ $1.794788($ Ijara $)+\mathrm{Ut}$}

Table 9. Long-Term Relationship Model Test Results

\begin{tabular}{lllll}
\hline Variable & Coefficient & Std. Error & t-Stat & Prob. \\
\hline C & -0.097659 & 0.054307 & -1.798285 & 0.0775 \\
MDH & 8.312396 & 3.368598 & 2.467613 & 0.0167 \\
MY & 5.045980 & 1.845975 & 2.733504 & 0.0084 \\
IJR & 1.794788 & 1.428674 & 1.255261 & 0.2142 \\
\hline R-squared & 0.319614 & Mean dependent var & 0.025000 \\
Adjusted R & 0.283164 & SD dependent var & 0.017833 \\
SE of regression & 0.015098 & AIC & -5.484150 \\
SS resid & 0.012765 & SIC & -5.344527 \\
Likelihood logs & 168.5245 & Hannan Quinn Criter. & -5.429536 \\
F-statistics & 8.768729 & Durbin-Watson stat & 0.569846 \\
Prob(F-statistic) & 0.000074 & & \\
\hline
\end{tabular}

Source: Secondary Data Processed Using Eviews 10, 2021

Variable Mudharaba with t- Statistic is 2.467613; the results of research data processing show that the Mudharaba variable has a positive coefficient. Then, the critical t-table in the t-table with $(0.05)$ and $\mathrm{df}=\mathrm{nk}(\mathrm{df}=60-3=57)$ is 2.002247 . So that it can be seen that the $\mathrm{t}$ - statistic ( $\mathrm{t}$-count) is greater than $\mathrm{t}$-critical $(2.467613>2.002247)$, then rejects Ho2, which means that in the long term, Mudharaba has a positive effect on return on equity (ROE). When the Mudharaba increased by $1 \%$, the total return on equity (ROE) decreased by 8.312396 million rupiahs assuming that other variables were constant. Variable Musharaka with t- Statistic of 2.733504, the results of research data processing show that the Musharaka variable has a positive coefficient. Then, the critical t-table in the t-table with $(0.05)$ and $\mathrm{df}=\mathrm{nk}(\mathrm{df}=60-3=57)$ is 2.002247 . So that it can be seen that the t- statistic (t-count) is greater than t-critical $(2.733504>2.002247)$, then rejects Ho4, which means that in the long term, musharaka has a positive effect on return on equity (ROE) . When Musharaka increased by $1 \%$, the total return on equity (ROE) decreased by 5,045980 million rupiahs, assuming that other variables were constant. Ijara variable with a t- statistic of 1.256261 , the results of research data processing show that the Ijara variable has a positive coefficient. Then comet-critical on-table $\mathrm{t}$ with $\alpha(0.05)$ and $\mathrm{df}=\mathrm{NK}(\mathrm{df}=60-3=57)$ which amounted to 2.002247. So it can be seen that $\mathrm{t}$-statistic $(\mathrm{t}$-count) is smaller than $\mathrm{t}$-critical $(1.256261<2.002247)$, so 
it accepts Ho6, which means that in the long term, the Ijara does not affect the return on equity (ROE) .

\section{Partial test ( $\mathrm{t}$-Test )}

The t-test shows how far the influence of one explanatory or independent variable is individually in explaining the variation of the dependent variable with a significance level of $=1 \%, 5 \%, 10 \%$. This test can be seen from the value of t- statistics and the probability of each variable. The results of the t-test can be seen in the following table 10:

Table 10. Partial Test Results (t-Test)

\begin{tabular}{lll}
\hline Independent Variable & t- Statistics & Probability \\
\hline Mudharaba & 2.833045 & 0.0065 \\
\hline Musharaka & 2.909601 & 0.0052 \\
\hline Ijara & 1.330407 & 0.1890 \\
Source: Secondary Data Processed Using Eviews & 10,2021
\end{tabular}

Based on the results from Table 10, it can be seen from the t- statistic of 2.833045 , a probability value of 0.0065 is obtained because the probability value is smaller than $=5 \%(0.0065<0.05)$, it can be concluded that the Mudharaba variable in the short term has a significant effect on return on equity (ROE).Based on the results from Table 4.10, it can be seen from the t- Statistic of 2.909601 that a probability value of 0.0052 is obtained because the probability value is smaller than $=5 \%(0.0052<0.05)$, it can be concluded that the short-term Musharaka variable has a significant effect on return on equity (ROE). Based on the results of Table 4.10, it can be seen from the tstatistic of 1.330407 that the probability value is 0.1890 . because the probability value is smaller than $=5 \%(0.1890>0.05)$, it can be concluded that the short-term Ijara variable has no significant effect on return on equity (ROE).

\section{Simultaneous Test ( F Test )}

The F statistical test shows whether all independent or independent variables included in the model affect the dependent variable. With the provision that if the probability value of the F- statistic is less than the significance level, namely $=1 \%, 5 \%$, and $10 \%$, the independent variables together affect the dependent variable. However, if the value of the F- statistic is greater than the significance level, i.e., $=1 \%, 5 \%$, and $10 \%$, the 
independent variables together have no significant effect on the dependent variable. The following is a table of test results from the $\mathrm{F}$ test:

Table 11. Simultaneous Test (F Test)

\begin{tabular}{lll}
\hline Score & F- Statistics & Prob (F-Statistic ) \\
\cline { 2 - 3 } & Secondary Data Processed Using Eviews 10, 2021
\end{tabular}

Based on Table 11 above, it can be seen that the probability value of the F- Statistic of 0.000828 is smaller than the value of $=0.005(0.000828<0.05)$, it can be concluded that simultaneously the independent variables are Mudharaba, Musharaka, and Ijara in the short term. Significant effect on return on equity (ROE).

\section{Coefficient of Determination Test.}

The determination test is used to measure the influence of the independent variable on the dependent variable, in this case, the influence of the value of the mudharaba, Musharaka, and ijara variables on the return on equity(ROE) of Bank Syariah Indonesia. The results of the determination test from the short-term regression show that the Adjusted R-Squared value is 0.238249 , which means that the independent variables, namely Mudharaba, Musharaka, and Ijara in the short term, affect the return on equity (ROE) of $23.8249 \%$ while the rest is Other factors outside the model were influenced by $76.1751 \%$.

\section{DISCUSSION}

\section{Effect of Mudharaba To Return On Equity (ROE)}

Mudharaba generates profits from profit sharing. The profits will be divided between customers and the bank to affect the rate of return on capital or return on equity (ROE) in Islamic banks. It can be seen by comparing profits with the capital they have. ${ }^{6}$ To test the hypothesis which states that Mudharaba has a positive and significant effect on return on equity (ROE) at Indonesian Islamic Banks for the 20162020 period, it can be done by looking at the results of the t-test (partial test) on Mudharaba .

Based on the short-term and long-term tests, Mudharaba affects return on equity (ROE). The short-term results show that the t- statistic (t-count) is greater than 
the t-critical $(2.833045>2.002247)$, which means that the short-term test rejects Ho1, and it can be concluded that in the short term, Mudharaba affects return on equity ( $\mathrm{ROE}$ ). While the results of the long-term test show. That the $\mathrm{t}$ - statistic (t-count) is more significant than t-critical $(2.467613>2.002247)$, which means that the long-term test rejects Ho2, and it can be concluded that in the long term, Mudharaba affects return on equity (ROE). If Mudharaba has increased, it can be said that profitability will also increase. Because the value generated from the Mudharaba will impact the profits obtained by the bank, these profits will also have an impact on increasing the percentage of Islamic bank profitability.

However, if there are obstacles in the distribution of to customers or the distribution is not smooth, this will also affect the percentage of profitability of the resulting Islamic bank. When the Mudharaba has an effect in the short term, it will increase customer interest in doing Mudharaba at BRI Syariah banks. And when the Mudharaba has an effect in the long term, it can attract investors to collaborate with BRI Syariah Bank. In this study, the short-term generated was 2,833,045, while the long-term generated was $2,467,613$. So in this short-term and long-term influence, it can be concluded that the short-term is more influential than the long-term. It can be concluded that Mudharaba has a partial effect on return on equity (ROE) at Indonesian Islamic Banks for the 2016-2020 period. The results of this study are in line with the research conducted by Mahmudin entitled "The effect of Mudharaba on the rate of return on equity (ROE) in Islamic banks registered with Bank Indonesia."

\section{Effect of Musharaka To Return On Equity (ROE)}

Musharaka will generate profits from the calculation for the result; the profits will be used for the return on capital allocated to the that will affect the rate of return on equity (ROE). ${ }^{7}$ To test the hypothesis that Musharaka has a positive and significant effect on return on equity (ROE) at Indonesian Islamic Banks for the 2016-2020 period, it can be done by looking at the results of the t-test (partial test) on Musharaka .Based on the short-term and long-term tests, Musharaka affects return on equity (ROE). The short-term results show that the $\mathrm{t}$-statistic (t-count) is greater than the t-critical (2.909601>2.002247), which means that the short-term test rejects Ho3, and it can be concluded that in the short term, musharaka affects return on equity( $\mathrm{ROE}$ ). Meanwhile, the results of the long-term test show that the t- statistic (t-count) is 
more significant than t-critical $(2.733504>2.002247)$, which means that in the long-term test, it rejects Ho4, and it can be concluded that in the long term musharaka affects return on equity (ROE). The coefficient is positive, meaning a positive relationship between musharaka and return on equity (ROE). The higher the musharaka, the higher the return on equity (ROE) percentage. Musharaka positively affects the return on equity (ROE) rate because Musharaka from 2016 to 2020 continued to rise. With this increase, the bank will get increased income, so that it will have an impact on increasing the percentage of profitability in Islamic banks. When the musharaka has an effect in the short term, it will increase customer interest in doing musharaka at BRI Syariah banks. And when the musharaka has an effect in the long term, it can attract investors to collaborate with BRI Syariah Bank. In this study, the short-term generated was $2,909,601$, while the long-term generated was $2,733,504$. So in this short-term and long-term influence, it can be concluded that the short-term is more influential than the long-term. It can be concluded that musharaka has a partial effect on the return on equity (ROE) in Indonesian Islamic Banks for the 2016-2020 period. Based on the short-term and long-term test, Ijara does not affect the return on equity (ROE). The short-term results show that the $\mathrm{t}$-statistic ( $\mathrm{t}$-count) is smaller than the $\mathrm{t}$-critical $(1.330407<2.002247)$, which means that in the short-term test, it accepts Ho5, and it can be concluded that in the short term, Ijara does not affect the return on equity. (ROE). While the results of the long-term test show that the t- statistic (t-count) is smaller than the t-critical $(1.256261<2.002247)$, It means that in the long-term test, it accepts Ho6, and it can be concluded that Ijara does not affect the return on equity (ROE) in the long term. The analysis showed that the Ijara does not affect the return on equity (ROE). It can be caused because it is still rarely used and slightest interest in Ijara. And there are several risks such as damage to goods and depreciation of goods which resulted in the bank still getting rental fees but having to bear the damage. The bank will issue the cost of damage, and depreciation of goods can affect Islamic banks' profit and reduce the return on equity (ROE).

In this case, Islamic banks must have good tactics and strategies related to damage to Ijara; this is for the advancement of Islamic banking, which will impact the level of return on equity (ROE). When the Ijara has no effect in the short term, it will impact the customer's interest in doing Musharaka at BRI Syariah banks to decrease and when the Ijara has no effect in the long term, it can result in at least investors 
cooperating with BRI Syariah Bank. In this research, the short-term result is 1.330407, while the long-term result is 1.256261 . So, in terms of short-term and long-term effects, it can be concluded that the short-term has the weakest effect on return on equity (ROE). It can be concluded that Ijara does not partially affect Indonesian Islamic banks' return on equity (ROE) for the 2016-2020 period. The results of this study are in line with research conducted by Zalfaa Hibatullah (2019) entitled "The influence of Mudharaba, musharakah, Murabaha, and Ijara on return on equity (ROE) at BCA Syariah banks", the results of the study stated that Ijara did not affect the return on equity (ROE).

\section{Effect of Mudharaba Musharaka and Ijara Against Return On Equity (ROE)}

Mudharaba, Musharaka, and Ijara simultaneously in both the short and longterm berbengaruh positive and significant impact on return on equity (ROE). It is evidenced by the short-term test where the value obtained from the Adjusted R-Squared is 0.238249, then rejects Ho7, which means that the independent variables, namely Mudharaba, Musharaka, and Ijara simultaneously in the short-term equation, affect the return on equity (ROE) of $23,8249 \%$ while other factors outside the model influence the remaining $76,1751 \%$. While the results of the long-term regression determination test obtained the Adjusted R-Squared value of 0.283164 which means that the independent variables, Mudharaba, Musharaka, and Ijara simultaneously in the long-term equation affect the return on equity (ROE) of 28, 3164\% while other factors outside the model influence the remaining $71.6839 \%$.

\section{CONCLUSION}

1. Mudharaba financing affects the return on equity (ROE) in the short and long term. Short-term and long-term tests evidence it. Short-term results show that the $\mathrm{t}$ - statistic ( $\mathrm{t}$-count) is greater than the $\mathrm{t}$-critical $(2.833045>2.002247)$. Meanwhile, the results of the long-term test show that the t- statistic (t-count) is more significant than t-critical $(2.467613>2.002247)$. So the short-term and long-term tests reject Ho1 and Ho2, meaning that Mudharaba financing affects the return on equity (ROE) in the short and long term.

2. Muysarakah financing in the short term and long term affects the return on equity (ROE). Short-term and long-term tests evidence it. The short-term results 
show that the $\mathrm{t}$ - statistic (t-count) is greater than the $\mathrm{t}$-critical (2.909601>2.002247). Meanwhile, the results of the long-term test show that the $\mathrm{t}$ - statistic (t-count) is more significant than t-critical $(2.733504>2.002247)$. So the short-term and long-term tests reject Ho3 and Ho4, meaning that muysaraka financing affects the return on equity (ROE) in the short and long term.

3. Ijara financing in the short and long term does not affect the return on equity (ROE). Short-term and long-term tests evidence it. Short-term results show that the $\mathrm{t}$ - statistic ( $\mathrm{t}$-count) is greater than the $\mathrm{t}$-critical $(1.330407<2.002247)$. Meanwhile, the results of the long-term test show that the t- statistic (t-count) is more significant than t-critical $(1.256261<2.002247)$. So in the short-term and long-term tests, accept Ho5 and Ho6, meaning that Ijara financing does not affect the return on equity (ROE) in the short and long term.

4. Financing Mudharaba, Musharaka, and Ijara simultaneously in both the short and long-term berbengaruh positive and significant impact on return on equity (ROE). It is evidenced by the short-term test where the value obtained from the Adjusted R-Squared is 0.238249 , then rejects Ho7, which means that the independent variables, namely Mudharaba, Musyaraka, and Ijara financing simultaneously in the short-term equation, affect the return on equity (ROE) of $23,8249 \%$ while other factors outside the model influence the remaining $76,1751 \%$. While in the long term, the Adjusted R-Squared value is 0.283164 , it rejects Ho8, which means that the independent variables, namely Mudharaba, Musyaraka, and Ijara financing simultaneously in the long-term equation affect the return on equity (ROE) of $28.3164 \%$. The rest of $71.6839 \%$ is influenced by other factors outside the model.

\section{REFERENCE}

Aditya, M. R. (2016). Pengaruh Pembiayaan Mudarabah dan Pembiayaan Musyaraka terhadap tingkat Profitabilitas Bank Umum Syariah Periode 2010-2014. Jurnal Profita, 4.

Andrianto, \& Firmansyah, A. (2019). Manajemen Bank Syariah Implementasi Teori dan Praktek. Jakarta: CV Penerbit Qiara Media.

Aziza, A. R. N., \& Diana, N. (2021). PENGARUH PEMBIAYAAN MUDHARABAH DAN MUSYAROKAH TERHADAP ROE PADA BANK BCA SYARIAH. Maro: Jurnal Ekonomi Syariah Dan Bisnis, 4(1), 34-43. https://doi.org/10.31949/maro.v4i1.842

Bank BRI Syariah. (2020). Retrieved 2 December 2020, from http://www.brisyariah.co.id 
Faradilla, C., Arfan, M., \& Shabri, M. (2017). PENGARUH PEMBIAYAAN MURABAHAH, ISTISHNA, IJARAH, MUDHARABAH DAN MUSYARAKAH TERHADAP PROFITABILITAS BANK UMUM SYARIAH DI INDONESIA. Jurnal Administrasi Akuntansi: Program Pascasarjana Unsyiah, 6(3). Retrieved from http://jurnal.unsyiah.ac.id/JAA/article/view/8775 Harahap, S. (2018). Study Kelayakan Bisnis. Medan: FEBI UIN-SU Press.

Satria, D. I., \& Saputri, H. (2016). Pengaruh Pendapatan Murabahah, Mudharabah, dan Musyarakah Terhadap Return on Equity PT Bank Syariah Mandiri. Jurnal Visioner \& Strategis, 5(2). Retrieved from https://journal.unimal.ac.id/visi/article/view/221

Soemitra, A. (2016). Bank \& Lembaga Keuangan Syariah. Jakarta: Prenada Media. Retrieved from https://books.google.co.id/books?id=0SFADwAAQBAJ

Soemitra, A. (2019). Hukum Ekonomi Syariah dan Fiqh Muamalah. Jakarta: Prenadamedia Group.

Wiroso. (2011). Produk Perbankan Syariah. Jakarta: LPFE Usakti. 